\title{
ПРОФІЛАКТИКА ТА ДОПОМІЖНЕ ЛІКУВАННЯ ГОСТРИХ РЕСПІРАТОРНИХ ЗАХВОРЮВАНЬ ДІТЕЙ І ДОРОСЛИХ ЗА ДОПОМОГОЮ БІОПТРОН-ПАЙЛЕР-СВІТЛА
}

С. О. Ґуляр

\author{
Інститут фрізіології ім. О. О. Богомольця НАН України \\ Інтернаціональний медичний інноваційний чентр Цептер
}

\begin{abstract}
Огляд містить короткі відомості про нові аспекти фрізіотерапії (фотобіомодуляції) із застосуванням поляризованого світла апарату БІОПТРОН. Палітра активних біофрізичних чинників налічує 12 полі- та монохроматичних видів світла від галогенних і світлодіодних джерел. Їхня протизапальна, протибольова, репаративна та імунонормалізуюча ефективність доведена експериментально та клінічно. Серед основних показів $€$ також різноманітні види патології шкіри та слизових оболонок, лікування ран і наслідків травм, оптимізація реабілітаційних процесів та інші стани, що підлягають фрізіотерапевтичному лікуванню. Додаткові специсрічні терапевтичні можливості виникають за рахунок створення монохроматичних (лазероподібних) діапазонів, модифрікації світла фууллереном із тороїдною поляризацією та розширений діапазон із додаванням ближнього ультрафіолетового світла. ПАИЛЕР-світло впливає як місцево на клітини та світлочутливі молекули, нормалізуючи в них електромагнітний баланс, так і системно через дію на структури крові та точки акупунктури.

Експериментально доведено бактерицидну та противірусну есективність БІОПТРОН-світла. Під час холодного сезону безконтактна неінвазивна профрілактика та лікування застудних захворювань із застосуванням БІОПтРОН-світлотерапії $€$ суттєвою для зменшення негативних проявів без фрармакологічного навантаження на організм. Наведено апробовані протокольні схеми просрілактики та лікування гострих респіраторних захворювань. Серед засобів індивідуального захисту доцільно зменшення світлового навантаження та створення механічних перепон для захисту очей шляхом застосування окулярів з фруллереновими фрільтрами.

Головною особливістю ЦЕПТЕР-технологій у цілому є їхня здоров'я-зберігаюча сутність, реалізована шляхом багаторівневого антиоксидантного захисту. Все це $є$ необхідним компонентом заходів, що застосовуються при гострих респіраторних захворюваннях.
\end{abstract}

Ключові слова: грип, нежить, гострі респіраторні захворювання, поляризоване світло, Біоптрон, Медолайт, фотобіомодуляція, вільні радикали, сруллерен, гіпоксія, окислювальний баланс.

\section{PREVENTION AND ADJUVANT TREATMENT OF ACUTE RESPIRATORY DISEASES OF CHILDREN AND ADULTS WITH BIOPTRON-PILER-LIGHT}

\section{S. A. Gulyar \\ Bogomoletz Institute of Physiology, National Academy of Sciences of Ukraine Zepter International Medical Innovation Center}

Background. The review contains brief information on new aspects of physiotherapy (photobiomodulation) using polarized light of the Bioptron device. The palette of its active biophysical components includes 12 types of poly- and monochromatic light from halogen and LED sources. Their anti-inflammatory, analgesic, reparative, immune-normalizing, antimicrobial and other efficacy have been proven experimentally and clinically. Among the main indications are also various types of pathology of the skin and mucous membranes, treatment of wounds and the consequences of injuries, optimization of rehabilitation processes and other conditions subject to physiotherapy treatment.

Materials and methods. Results. Additional specific therapeutic possibilities arise due to the creation of monochromatic (quasilaser) ranges, light modifications with fullerene with toroidal polarization and an extended range with the addition of near-ultraviolet light. PILER-light acts both locally on cells and photosensitive molecules, normalizing the electromagnetic balance in them, and systemically through influence on blood structures and acupuncture points.

The bactericidal and antiviral efficacy of BIOPTRON light has been experimentally proven. During the cold season, non-invasive prophylaxis and treatment of colds with the help of BIOPTRON light therapy is essential to reduce negative manifestations without pharmacological burden on the body. The protocols for the prevention and treatment of acute respiratory diseases have been tested. Among personal protective equipment, it is advisable to reduce the light load and create mechanical obstacles to protect the eyes by using glasses with fullerene filters.

Conclusions. The main feature of ZEPTER technologies as a whole is their health-saving essence, realized through multilevel antioxidant protection. All this is a necessary component of the measures used in case of acute respiratory diseases.

Key words: influenza, colds, acute respiratory diseases, polarized light, Bioptron, Medolight, photobiomodulation, free radicals, fullerene, hypoxia, oxidation balance. 


\title{
ПРОФИЛАКТИКА И ВСПОМОГАТЕЛЬНОЕ ЛЕЧЕНИЕ ОСТРЫХ РЕСПИРАТОРНЫХ ЗАБОЛЕВАНИЙ ДЕТЕЙ И ВЗРОСЛЫХ С ПОМОЩЬЮ БИОПТРОН-ПАЙЛЕР-СВЕТА
}

С. А. Гуляр

\author{
Институт фризиологии им. А. А. Богомольца НАН Украины \\ Интернациональный медицинский инновационный центр Цептер
}

\begin{abstract}
Обзор содержит краткие сведения о новых аспектах фризиотерапии (фотобиомодуляции) с применением поляризованного света аппарата БИОПТРОН. Палитра его активных биофизического фракторов насчитывает 12 видов поли- и монохроматического света от галогенных и светодиодных источников. Их противовоспалительная, противоболевая, репаративная, иммунонормализующая, антимикробная и другие эффрективности доказаны экспериментально и клинически. Среди основных показаний также различные виды патологии кожи и слизистых оболочек, лечение ран и последствий травм, оптимизация реабилитационных процессов и другие состояния, подлежащие фризиотерапевтическом лечению.

Дополнительные специфические терапевтические возможности возникают за счет создания монохроматических (лазероподобных) диапазонов, модификаций света фуллереном с тороидальной поляризацией и расширенный диапазон с добавлением ближнего ультрафиолетового света. ПАИЛЕР-свет воздействует как местно на клетки и светочувствительные молекулы, нормализуя в них электромагнитный баланс, так и системно через воздействие на структуры крови и точки акупунктуры.

Экспериментально доказана бактерицидная и противовирусная эфрфективность БИОПРОН-света. Во время холодного сезона бесконтактная неинвазивная просрилактика и лечение простудных заболеваний с применением БИОПТРОН-светотерапии является существенной для уменьшения негативных проявлений без фармакологической нагрузки на организм. Приведены апробированные протокольные схемы профилактики и лечения острых респираторных заболеваний. Среди средств индивидуальной защиты целесообразно уменьшение световой нагрузки и создание механических препятствий для защиты глаз путем применения очков с фруллереновыми срильтрами.

Главной особенностью ЦЕПТЕР-технологий в целом является их здоровье-сберегающая сущность, реализованная через многоуровневую антиоксидантную защиту. Все это является необходимым компонентом мероприятий, применяемых при острых респираторных заболеваниях.
\end{abstract}

Ключевые слова: грипп, простуда, острые респираторные заболевания, поляризованный свет, Биоптрон, Медолайт, фотобиомодуляция, свободные радикалы, фуллерен, гипоксия, окислительный баланс. 
Introduction / Real story. Ordinary kindergarten. In autumn, tempered and tanned children gather in a nursery school or preschool or school institution. The parents' pink dreams are shattered in a week or two when someone begins to become ill, and the rate of a cold causes to keep the baby at home again and treat, often hopelessly. In one of Kharkiv's kindergartens, one of the tutors had a portable BIOPTRON device that produces healing light. The children in her group were getting sick, like everyone else, but a wise tutor, every time her children returned from a walk with wet noses lighted on every nose, which quickly stopped to sniff. When, in spring, the results were summarized, it turned out that, compared to the normal control group, acute viral respiratory infection was reported in only $67.5 \%$ of children, acute bronchitis in $67.6 \%$, otitis in $56.5 \%$, sinusitis - in $58.3 \%$, and only $64.4 \%$ of children [22-23] went to see a doctor. Such a striking result has not yet been seen in the practice of care in a standard preschool institution. Why it is advisable to understand what are the benefits of new preventive and treatment technology, what devices provide it, what physical factors it creates, and what mechanisms of local or systemic influence give positive effects - will be discussed below. The ultimate goal is to introduce non-contact therapies to prevent long-term adverse effects of multiple colds in childhood.

What is relevant for now. Late fall, winter, spring - for many parents, who care about the health of their young posterity, is time to try not only more intensive care for the baby, but also to prevent colds or treat them. Health immunity acquired during the summer is gradually depleted and the body becomes more vulnerable to adenoviral infections. If a child attends children's groups, the threat of getting a respiratory bouquet becomes almost inevitable. Sick child is a powerful destabilizer of the modern family, which eliminates the mother from active life, creates parental stress, affects the wallet, and so on. Vaccination, with all due respect to the advances in immunology, is regularly delayed in the development of topical vaccines, and is often inertial to last year's or the year before last influenza viruses, not to mention that it is also a certain strain on the body. The inappropriate use of antibiotics has already been proven, and antivirus drugs are not yet sufficiently effective, and their chemical effects do not improve the condition of the liver, kidneys, heart ... Winter shortage of solar energy adds the negative and contributes to the development of affective disorder syndrome with immune and mental depression, decreased performance, drowsiness, etc.
Is there light at the end of the tunnel? Is it possible to prevent, alleviate or cure «common» colds? And to do it without chemical or antigenic loading, injections and baby fear? It turned out to be yes, and this makes polarized light of a wide (solar) range.

Historical stairs. The first light used for therapeutic or prophylactic purposes was sunlight. The scientific rationale for this trend emerged at the beginning of the last century, when Danish physician H.R. Finsen was awarded the Nobel Prize for his contribution to the light therapy of skin. After 50 years, laser was invented and it turned out that its light could not only destroy, but also restore tissue. The ranges of ultraviolet, narrow monochromatic or infrared emission spectra were used. Researchers considered the degree of polarization of light as an important indicator. In 1981, a group of Hungarian researchers created a quasilaser device; it differed in polarization which was achieved more economically and the light was polychromatic, i.e. it combined the visible and infrared spectra. Based on this technology, a family of BIOPTRON light therapy devices was created.

The aim of the study: to acquaint with the on new aspects of physiotherapy (photobiomodulation) using polarized light of the Bioptron device.

General features of Bioptron light therapy. Recent studies have shown that the effect of polychromatic polarized light on the human body extends to a wide variety of preventive and therapeutic effects, such as activation of regeneration processes, suppression of inflammation, normalization of immune processes, desensitization and vasoactivity, vegetotropic, psychotropic, analgesic action and the like. There are opportunities to increase the impact of other methods of physiotherapy, drug treatment, psychotherapy, physical therapy, rehabilitation, improve the care of infants, preschoolers, mothers or the elderly people through the appointment of various modes of light therapy.

Device base. There are three models of light therapy devices: BIOPTRON-MedALL, BIOPTRON-PRO-1 and BIOPTRON-2. Manufacturer: BIOPTRON AG, ZEPTER GROUP, Switzerland [2, 10] (Fig. 1).

BIOPTRON-MedAll (flux diameter $5 \mathrm{~cm}$ ) is designed to influence small areas or for zone-based and acupuncture-based therapy. It is equipped with a built-in timer to mark the duration of the procedure. Option - floor stand.

BIOPTRON-PRO-1 (flux diameter $11 \mathrm{~cm}$ ) provides higher phototherapy performance while maintaining compactness and mobility. Equipped with a built-in timer for up to 99 minutes of exposure with automatic light off and two variants of stands (for table and floor). 
BIOPTRON-2 (flux diameter $15 \mathrm{~cm}$ ) is preferred for a wider field of influence, for example for the treatment of lesions of large areas of the skin, in burn surgery, for immuno-normalization and the like. Has an electronic timer for 1-99 minutes of exposure and automatic shutdown of light. Option - floor stands.

Each of BIOPTRON devices can be used at home and in professional medical practice (polyclinic and stationary medical establishments, children's establishments, cosmetology cabinets, fitness centers, etc.).

Characteristics of the light emitted by devices. The light of the BIOPTRON devices, also called PILER (Polarized, Incoherent, Low Energy Radiation) has the same properties regardless of the model $[2,10]$.

- Polarization: Unlike multidirectional multiply reflected photons of scattered light, polarized waves are ordered, one-way and oscillate in one plane. This property causes a higher permeability of light electromagnetic waves into the skin, skin vessels and nerve structures without concomitant damage. Application of a fullerene filter adds toroidal hyperpolarization, which enhances the biological effect $[3,11,16]$.

- Polychromaticity: covers the full range of the visible and near part of the infrared spectrum. Ultraviolet radiation is absent, but there is an additional opportunity to obtain near soft UV rays (UVA, from $320 \mathrm{~nm}$ ), which are used with appropriate caution in physiotherapy.

- Incoherence: electromagnetic waves of PILERlight are not synchronized, do not coincide in phase, i.e. they oscillate at different frequencies;

- Low energy: in the wide electromagnetic range (visible light and near infrared radiation), each of the waves is not mutually amplified. This means that the energy of a single wavelength range does not exceed the total energy of the full luminous flux. Therefore, light has a constant low energy density and has no biologically destructive effect. In fullerene light the energy of the whole spectrum is reduced and its blue part is absent.

Depending on the color of the light filter that can be used with BIOPTRON (red, orange, yellow, green, light blue, indigo, violet) or without the main filter (UVA+PILER $320 \mathrm{~nm}$ ), it is possible to obtain polarized monochromatic light of the corresponding part of optical or ultraviolet spectra.

How BIOPTRON polarized light works. A biological reaction can only occur when the quantum of light is absorbed. The energy of absorbed quanta in biological molecules changes their energy state. This makes it possible to act in agreement with numerous enzymes in living cells, and provides them with metabolism, which has a decisive influence on the processes of restoration of normal functions of the body.

The following basic mechanisms of therapeutic action of polarized light have been experimentally established.

These include local restoration of skin cell or mucous membrane functions, transdermal effects on capillary motility, as well as other skin structures, and activation of reflexogenic zones (acupuncture points) [2, 9, 10, $18,21]$.

It turned out that under the influence of polarized light on the pain locus, the pain systems of the brain are significantly activated simultaneously with the correction of the inflammation process, reduction of edema, increased microcirculation, etc. Thus, the biological action of polarized light is manifested at the molecular, cellular and systemic levels.

Main directions of BIOPTRON-light therapy application in pediatrics. The basic indications cover main therapeutic capabilities of the PILER light. These include the correction of many types of pathology of the skin and mucous membranes, positive modification of immunity, treatment of wounds and consequences of injuries, pain relief, optimization of processes of postpartum development $[14,15$, 17, 22, 23]. Indications are states that are subject to physiotherapy. Specific therapeutic options and indications are determined based on understanding the mechanisms of PILER-light action in different wavelengths ranges (white polychromatic, seven color monochromatic, shortwave infrared, longwave ultraviolet). They, in turn, determine the lists of states and diseases, as well as treatment regimens that are recommended for practical use.

For the infant body, the bio-normalizing effect of the PILER light is important, as there are activated the most important processes of life of the growing organism. Under the influence of light, protective capabilities are enhanced by enhancing immune processes, phagocytic activity of leukocytes, enhancing the tone of nervous processes, accelerating the maturation of individual tissues or joints, normalizing the activity of endocrine glands, phosphorus-calcium metabolism, etc.

Application of a monochromatic (color) light factor is based on the selectivity of the response of individual cellular mechanisms. Physiological and psychophysiological effects of color have been found, for example, for red (treatment of varicella, scarlet fever, measles and some skin diseases has been known since the Middle Ages). The positive effects of 
blue and purple have been proven in the treatment of neurological diseases, and green - for the correction of psychopathic disorders. The red and yellow components have produced interesting results in the treatment of apathetic and anemic states in children (increase in red blood cells, increase in body weight, and increase of its activity and improvement of mood). Blood bilirubin absorbs the blue part of the spectrum (wavelength $460 \mathrm{~nm}$ for bound bilirubin and $440 \mathrm{~nm}$ for unbound), resulting in photochemical hydrolysis of its excess in the jaundice (hyperbilirubinemia) of the infant. In this case, the effect of indigo-blue light on the widest area of skin (whole body) is indicated. The metabolites are excreted in the bile and urine, which does not disrupt DNA synthesis in liver and brain cells, thus reducing the risk of bilirubin encephalopathy [2].

Some methodological features of light therapy. The peculiarity of using polarized light for children lies in the duration of application (dose load) and changes with age. For infants and toddlers ( 0 - 3 years old), short exposures (2-6 min) should be used for treatment of atopic dermatitis, bronchitis, intertrigo and urticaria, and longer (6-10 min) for older children. The duration of treatment depends on the type of disorder, their localization, the speed of reparative processes and individual photosensitivity and ranges from one to several weeks or months, and without time constraints (for example, to prevent autumn-winter morbidity). After the session, you can apply natural creams, cosmetics and herbal remedies. It is advisable to combine the course of light therapy with the use of antioxidant drugs, especially for long-term treatment.

Application of local oxygenation by OXYSPRAY. OXYSPRAY, which is included in the BIOPTRON device set, is a solution of oxygen in sterile distilled water in an aerosol dispenser under high pressure [10]. Due to a special technology, the oxygen content is increased up to $500 \%$ compared to the usual oxygen concentration in water, i.e., compared to $5 \mathrm{mg} / \mathrm{l}$ (tap water), OXYSPRAY contains about $27 \mathrm{mg} / \mathrm{l}$. Compression of gas and water from the balloon is performed by compressed oxygen. It is a natural product that does not contain other impurities, is harmless to the respiratory system, skin, as well as the environment. The skin should be cleaned before using OXYSPRAY, and after one or two seconds of spraying the aerosol from a distance of about $20 \mathrm{~cm}$ for maximum effect, the skin should not be wiped and left to dry completely. BIOPTRON light should be applied at this time.

The additional processing of the treatment area with OXYSPRAY enhances penetration of water and oxygen into the cells. This achieves their hydration (waterfilled of dehydrating cells, wrinkle-reducing) and oxygenation (elimination of local oxygen deficiency, restoration of tissue respiration). In addition, the activity of oxygen as an oxidant contributes to its mild disinfectant action. OXYSPRAY is also a tonic that is recommended when person feel fatigue, including muscles and skin of the face. OXYSPRAY effectively acts on the inflamed areas of skin (irritations, pus, eczema, psoriasis, wounds, burns, etc.).

Practical application of BIOPTRON devices: colds. The most common diseases of the cold season are a variety of colds of the nose and its paranasal sinuses, throat, ears, larynx, trachea, and lungs [17]. Influenza (flu) is among the leading ones.

Flu is an acute respiratory disease caused by viruses that mutate each season. In this regard, in those who are ill, immunity arises only to a particular strain of the virus, and it is insufficient with the appearance of a new strain. The disease is characterized by acute rhinitis, high body temperature, and catarrhal changes of the upper respiratory tract, in severe cases - «creeping» of the infection into bronchioles and alveoli and pneumonia. Standard treatment and prevention measures include the use of vaccines that are appropriate for the virus strain, antiviral drugs, antioxidant and symptomatic agents, good nutrition, prevention of cooling, and the like. The effectiveness of the PILER-light application for the treatment of influenza has been experimentally proven. Studies of animals infected with the lethal dose of influenza virus showed that, while the control group had a $100 \%$ mortality rate, in the experimental one, with application of PILER-light to nasal, mortality was less than $50 \%$ [1]. In view of this and seasonal phases and epidemics, complex measures have recently been proposed to prevent, reduce the onset of influenza symptoms and accelerate recovery from influenza and adenoviral respiratory diseases applying BIOPTRON device (Table 1). 
Protocol of preventive and therapeutic actions using PILER-light during influenza, adenoviral and other seasonal acute respiratory diseases

\begin{tabular}{|c|c|}
\hline BIOPTRON-PILER-light therapy & Adjuvant methods \\
\hline $\begin{array}{l}\text { At risk of infection with virus influenza: } \\
\text { Prophylactic 6-10 minute light applications } \\
\text { (BIOPTRON-Pro-1, BIOPTRON-MedAll, } \\
\text { BIOPTRON-2) to the nose, mucous membranes of the } \\
\text { nose, mouth and eyes (white or blue light) } 1-2 \text { times a } \\
\text { day and after each stay in the cold air. Applications of } \\
\text { UVA+PILER-light (device without filter) to the nostril } \\
\text { (4 min, distance } 1-2 \mathrm{~cm} \text {, eyes closed). }\end{array}$ & $\begin{array}{l}\text { Staying in rooms with Therapy Air Ion — dust, germs } \\
\text { and allergen cleaner. } \\
\text { Fullerene glasses during light applications and under } \\
\text { sunlight }[12,13] \text {. }\end{array}$ \\
\hline $\begin{array}{l}\text { At the first signs of respiratory ailment: } \\
\text { Light applications to the nose (white and blue), into } \\
\text { the mouth (UVA+PILER-light - } 2-4 \text { min or indigo } \\
-8 \text { min), on the sternum (PILER-light }-20 \text { min). } \\
\text { Applications of UVA+PILER-light (without filter) to } \\
\text { the nostril ( } 4 \text { min, distance } 1-2 \mathrm{~cm} \text {, eyes closed). }\end{array}$ & $\begin{array}{l}\text { Staying in rooms with Therapy Air Ion - dust, germs } \\
\text { and allergen cleaner. } \\
\text { Processing of the room air by UVA+PILER } \\
\text { (BIOPTRON-PRO-1 or BIOPTRON-MedAll without } \\
\text { filter) [19, 20]. } \\
\text { Intake of antioxidant complexes: vitamins C, E, B, P, } \\
\beta \text {-carotene, flavonoids, etc.) [8]. } \\
\text { Fullerene glasses during light applications and under } \\
\text { sunlight. }\end{array}$ \\
\hline $\begin{array}{l}\text { Against the background of influenza (including } \\
\text { catarrh and bronchitis irrespective of the body } \\
\text { temperature): } \\
\text { 10-min light applications every 2-3 h into the } \\
\text { nose (white and blue), into the mouth (indigo in } \\
\text { combination with irrigation by OXYSPRAY), twice } \\
\text { a day to the sternum and sacrum (for } 20 \text { min), to the } \\
\text { projection of the roots of the lungs to the right and } \\
\text { left, to the supraclavicular zone. In the presence of } \\
\text { complications (otitis, sinusitis, frontitis) - light } \\
\text { (white, blue) applications to the projection of the } \\
\text { pathology locus in combination with instillation of a } \\
\text { vasoconstrictor (up to } 3 \text { days) into the nose. Auricles, } \\
\text { palms, soles - } 10 \text { min each. }\end{array}$ & $\begin{array}{l}\text { Staying in rooms with Therapy Air Ion - dust, germs } \\
\text { and allergen cleaner. } \\
\text { Processing of room air with UVA+PILER-light } \\
\text { (devices BIOPTRON-Pro-1 or BIOPTRON-MedAll } \\
\text { without filter). } \\
\text { Intake of antioxidant complexes. Fullerene glasses } \\
\text { during light applications and under sunlight. } \\
\text { Immuno-normalizing mixture (example): crushed aloe } \\
\text { leaves, honey, butter, cocoa in equal parts slightly } \\
\text { warmed in a ZEPTER tableware/pan (within the } \\
\text { yellow temperature regime) - } 1 \text { tsp. } 3 \text { times a day). } \\
\text { The use of dietary food cooked according to Zepter } \\
\text { technology and water without salts and impurities } \\
\text { (reverse osmosis). } \\
\text { General symptomatic treatment, if indicated - } \\
\text { oxygenation and resuscitation measures. }\end{array}$ \\
\hline $\begin{array}{l}\text { During recovery: } \\
\text { Two } 10 \text { min light applications to the nose (white and } \\
\text { red) and after each stay in the cold air, to the sternum } \\
\text { ( } 20 \text { min). } \\
\text { Intake of antioxidant complexes. } \\
\text { In case of the complications threat - symptomatic } \\
\text { treatment. } \\
\text { Fullerene glasses during light applications and under } \\
\text { sunlight. } \\
\text { Immuno-normalizing mixture (see above). }\end{array}$ & $\begin{array}{l}\text { Staying in rooms with Therapy Air Ion — dust, } \\
\text { germs and allergen cleaner. Processing of room } \\
\text { air with UVA+PILER-light (BIOPTRON-Pro-1 or } \\
\text { BIOPTRON-MedAll devices without filter). }\end{array}$ \\
\hline
\end{tabular}

Treatment regimens are compiled on the basis of the indications, state of the patient and individual effectiveness of a particular type of light. 


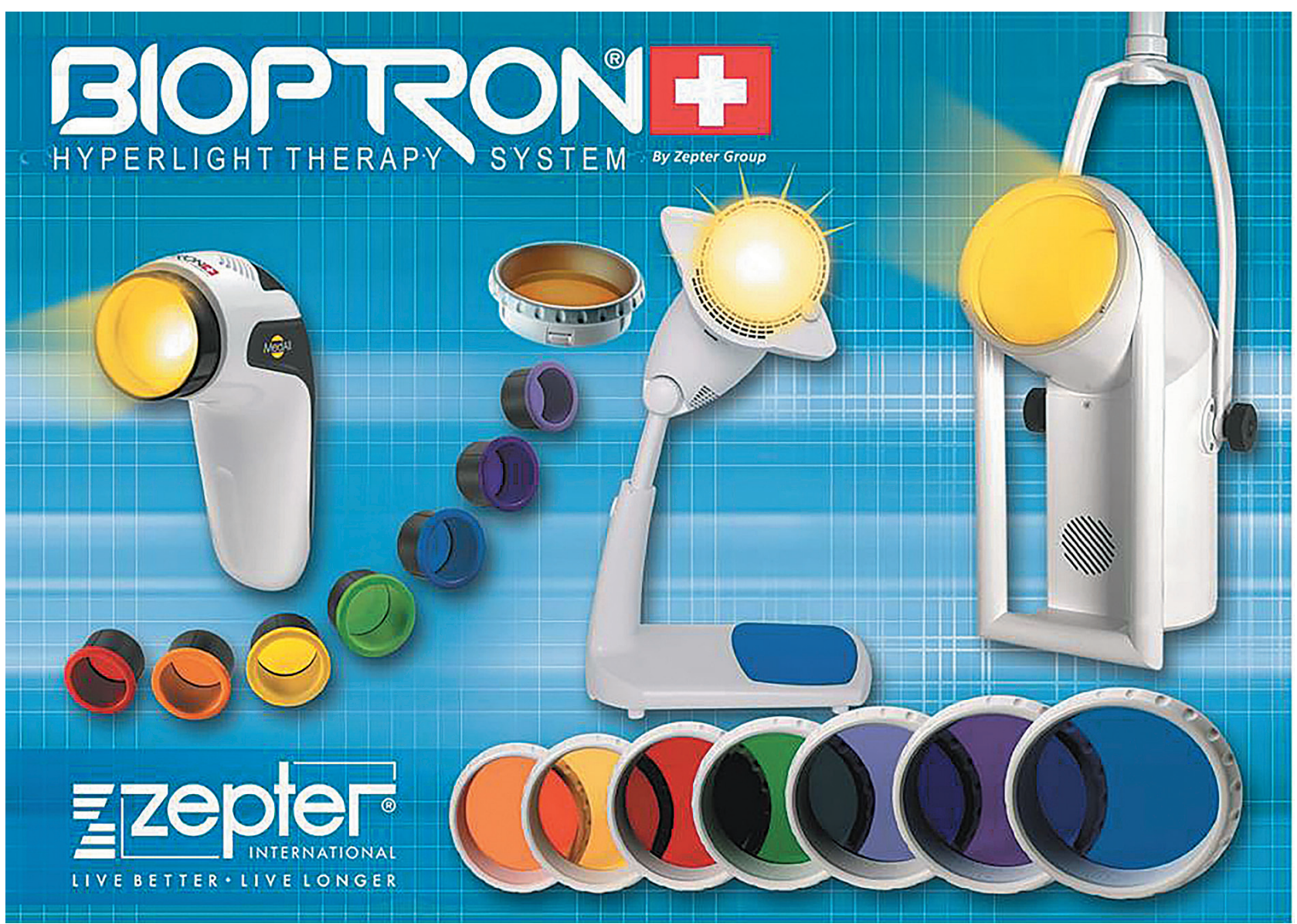

Fig. 1. BIOPTRON devices completed with monochromatic filters

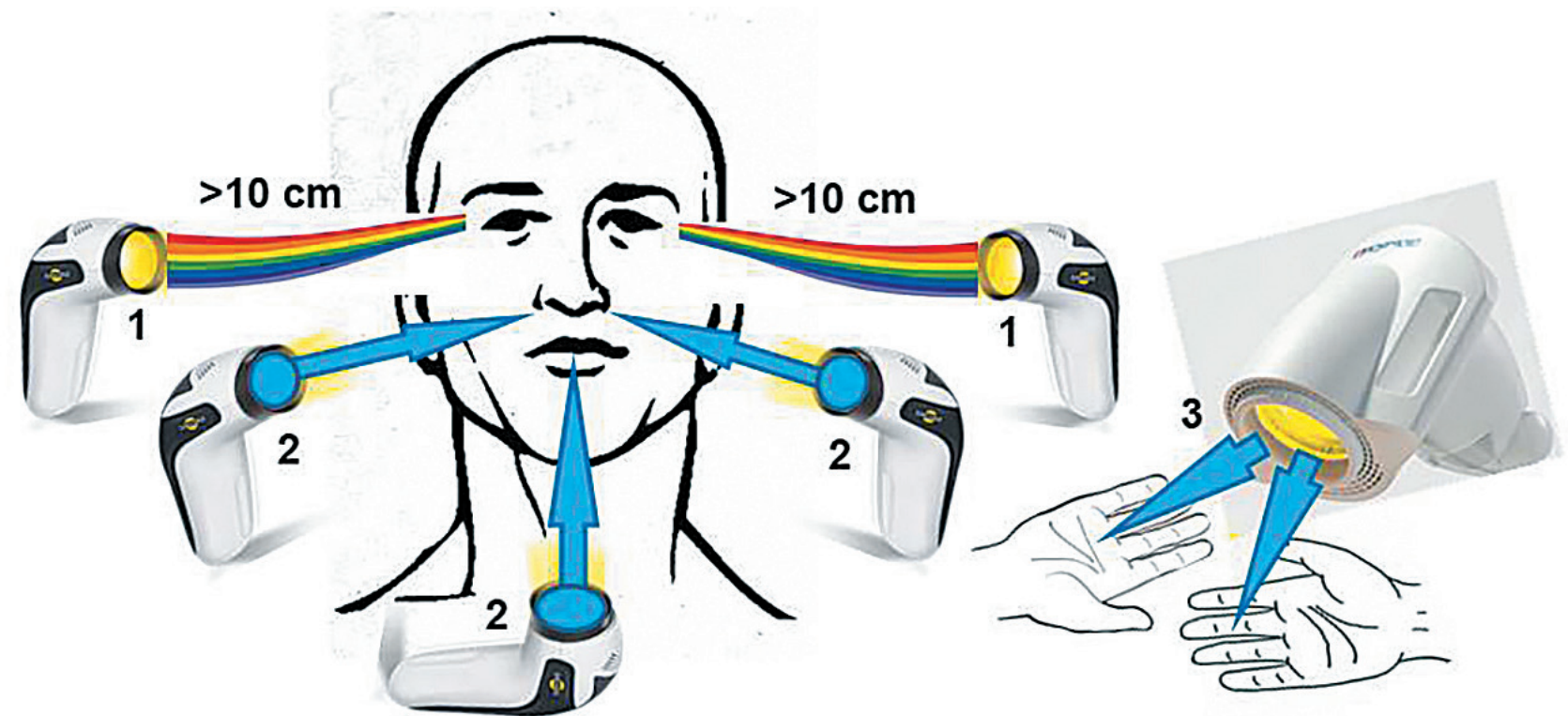

Fig. 2. The scheme of zones for active local protection of the mucous membranes in case of threat or consequences of contact with a virus-containing environment: 1 - applications of polychromatic light to the open eye (the beam is directed from the side from a distance of more than $10 \mathrm{~cm}$ ), 2 - applications of UVA+PILER or violet light to the nostrils and oral cavity, 3 - palms and other direct contact areas are treated by UVA+PILER. Exposition $10 \mathrm{~min}$ 


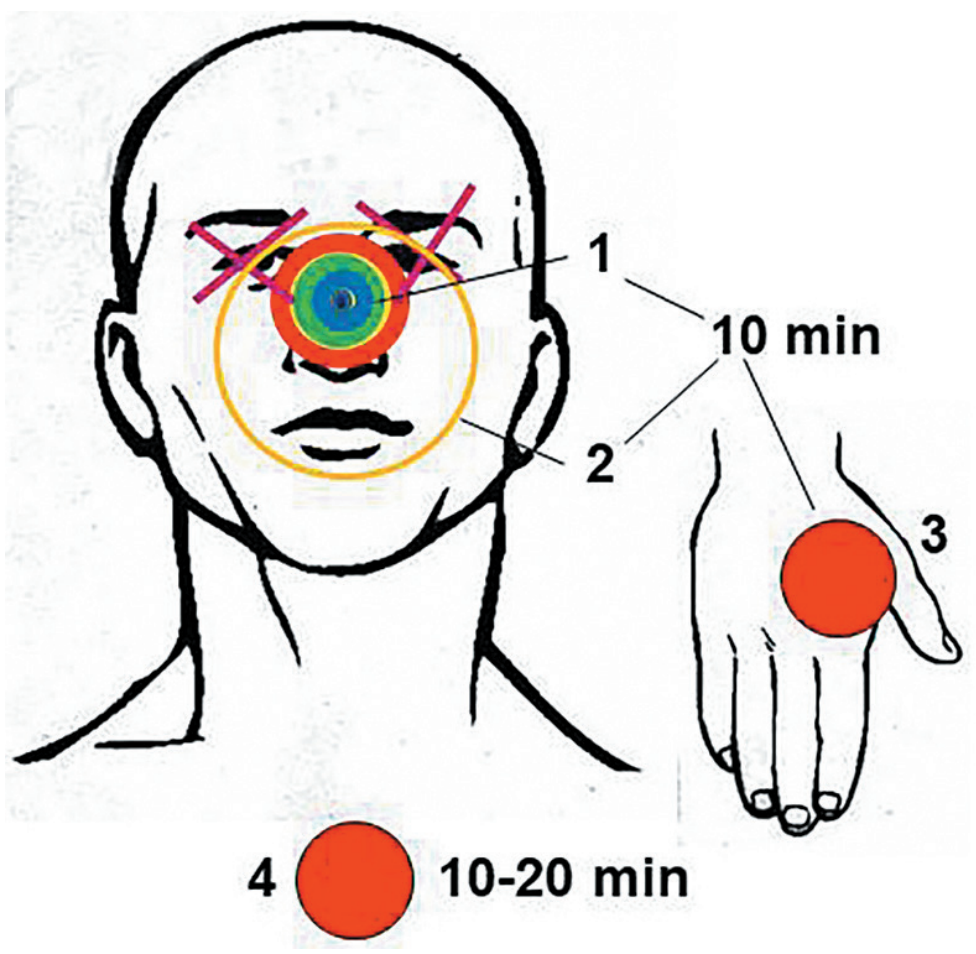

Fig. 3. The scheme of light treatment zones for optimizing nasal breathing and the accompanying effects: 1 - nose bridge (polychromatic light), 2 - beam coverage area of the BIOPTRON-Pro-1 device, 3 - He Gu (Gl-4) acupoint, 4 - sternum
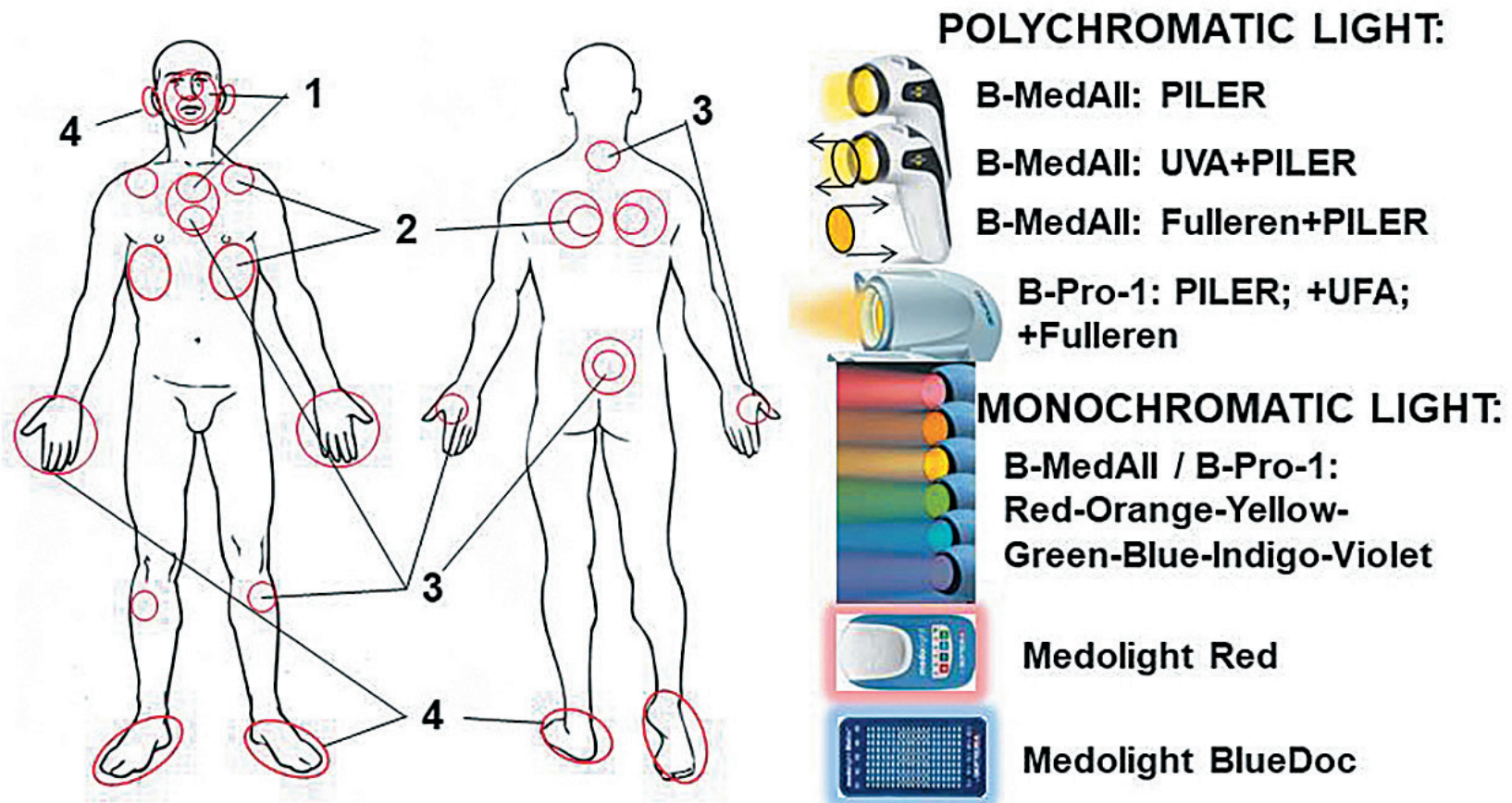

Fig. 4. The main areas used for correction of acute respiratory diseases: 1 - zones anatomically associated with the upper respiratory tract; 2 - zones of the pulmonary structures projection (apex, roots, separate lobes of the lungs); 3 - reflex-therapy zones for immune normalization: sternum, sacrum; 7th cervical vertebra, $\mathrm{Zu}$ San Li (E-36) and He Gu (Gl-4) acupoints; 4 - multifunctional zones (auricles, palms, soles of the feet); on the right are shown devices for light therapy and the types of light that they create. Exposure time 10-20 minutes 

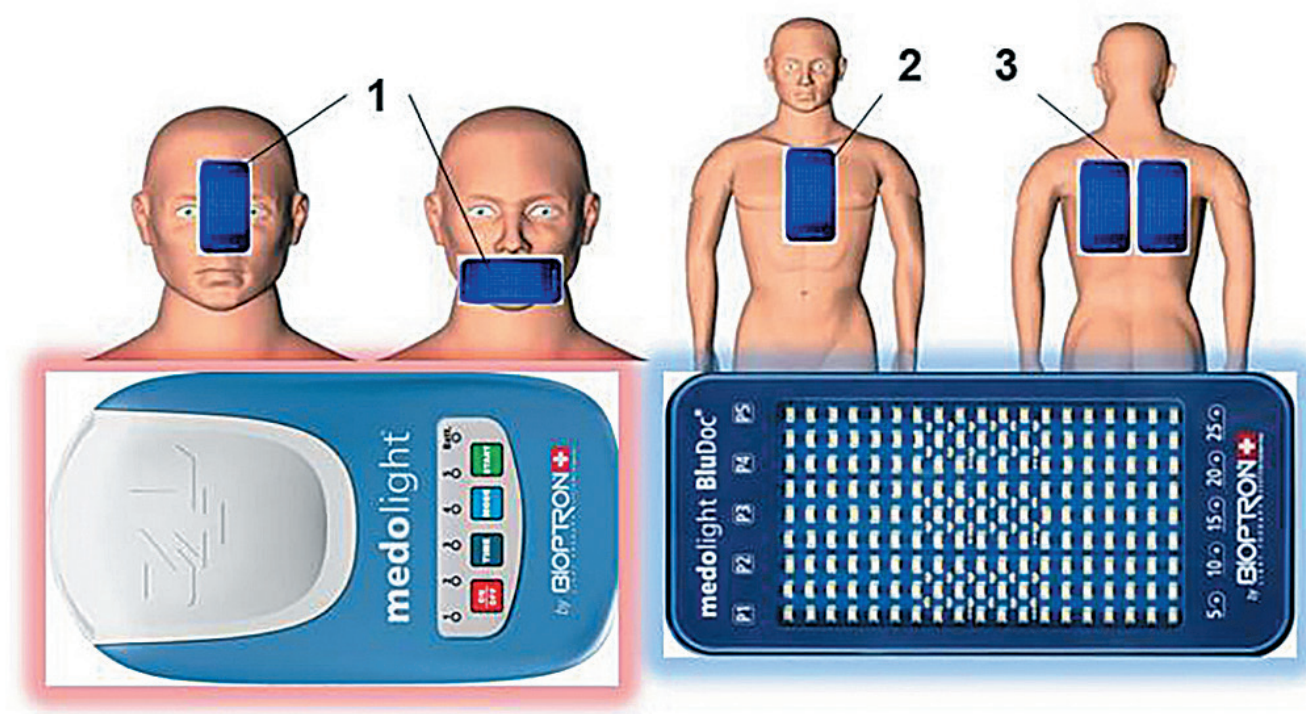

Fig. 5. The main areas used for mobile express correction of the acute respiratory diseases: 1 - zones anatomically connected with the upper respiratory tract, 2 - projection of the trachea, multifunctional immuno-normalizing zone, 3 - projection of the roots of lungs; below - LED devices Medolight and Medolight-BlueDoc

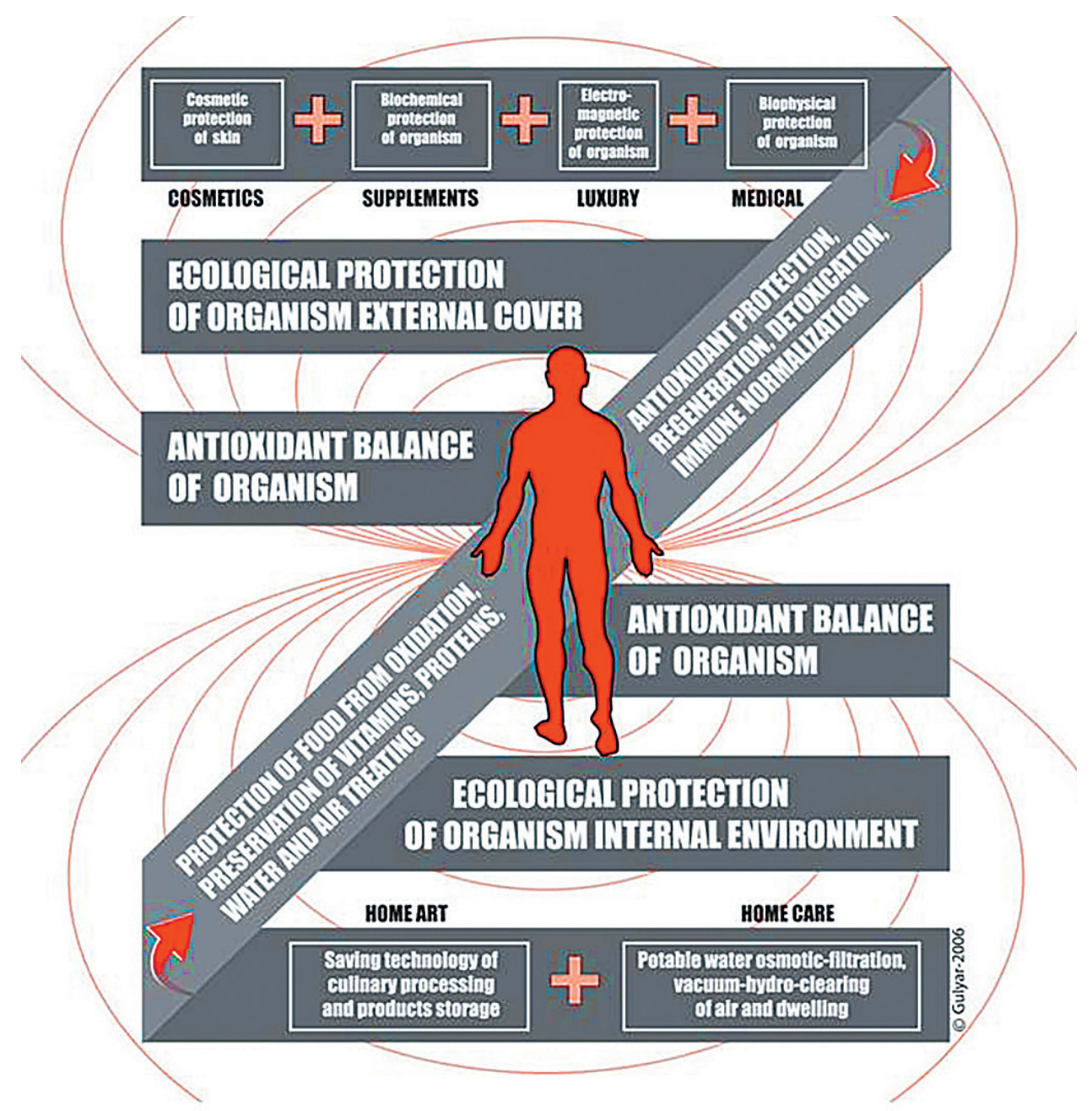

Fig. 6. General scheme of antioxidant ZEPTER technologies [4, 5]: Explanations in the text 
Hypoxic Disorder Prevention. It is well known that respiratory and metabolic systems can create the ability to increase resistance to oxygen starvation in the human body. This is achieved by training high in the mountains or staying in a hypobaric chamber. However, a similar result can be obtained in a more natural way. The special urgency of emergency adaptation assistance has appeared in connection with seasonal as well as over-planned flu attacks.

A peculiarity of modern complications of acute respiratory disorders of influenza origin is rapid development of pneumonia. This destroys the oxygen transport from the alveoli to blood, which leads to rapidly developing hypoxia. Its feature is the lack of time to develop adaptation to hypoxia, which usually manages to develop with slowly progressing processes.

The main pathophysiological syndrome is caused by the lack of oxygen delivery (energy quanta) to the mitochondria. It manifests itself in weakening of enzymatic processes, accumulation of products of incomplete metabolism, development of oxygenfree (peroxide) oxidation. Violations of biochemical processes caused by oxygen deficiency lead to the formation of a toxic stream of half-decomposed molecules (free radicals).

The tissues condition is exacerbated by violation of the adenosine triphosphoric acid synthesis (ATP) and energy imbalance. The body has its own antioxidant system, the task of which is to neutralize free radicals. However, it is designed for the «planned» intake of free radicals arising from natural metabolism, and is rapidly depleted under extreme loads. Thus, oxidative stress becomes the leading in influenza infection of the lungs. Therefore, the restoration of antioxidant balance becomes the main therapeutic task [2].

Even in the ordinary life of modern man the variety of outer ways in which free radicals penetrate into the body (air, water, food) practically do not leave him any chances to evade their destructive effect. The property of extremely active chemical reactions with intact biomolecules (lipids, proteins, enzymes) leads to the creation of peroxide compounds, which also act in a similar way. This worsens the damage of the key links of energy homeostasis up to their complete failure. Particularly sensitive are structures containing lipids, primarily cell membranes. Under conditions of free radicals' excess, peroxidation progresses and, if not neutralized, intermediate products accumulate, leading to premature wearing of cellular structures and systems of the body.

Against this background, a new stressor, leading to a rapid decrease in the efficiency of oxygen transport in pathways (influenza pneumonia), becomes a lifethreatening agent. That is why during the onset of the epidemic, when there is still no direct infection or against the background of the incubation period, preventive measures are vital.

The said above indicates that the main resultant characteristic of protective-compensatory (antiperoxide) capabilities of the body is the antioxidant balance. Its state, in turn, depends on the capabilities of the body's antioxidant system that chemically neutralizes free radicals, the intensity of these chemically active agents coming from the outside, their endogenous production, especially in pathological processes. The essential effect has presence of abnormal zones in which microcirculation disorders predominate, there is hypoxia, hypercapnia and discoordination at the expense of electromagnetic imbalance. Therefore, any effective ways to reduce peroxidation in the body must be considered the basic prerequisite for successful treatment.

Let us note that the pharmacological approach for direct neutralization of the virus is ineffective because of its encapsulation inside the cell. The biophysical approach involves direct and indirect delivery of energy to the zones of its deficiency and thus creates the conditions for enhancing the natural defense of cellular structures.

Considering medical, physiological and environmental aspects of protection against the aggression of free radicals, one cannot fail to note the additional opportunities obtained by using the full range of ZEPTER technologies. The leading ZEPTER technologies presented in the diagram (Fig. 6) are precisely united by a common approach aimed at normalizing the oxidation balance: improving oxygen supply and reducing peroxidation. This is achieved by corrective actions both on the external shell of the body and on its internal medium. The application point and the level of biochemical or electromagnetic protection in each case are not the same - from cell membranes to organ-system membranes, which creates a multilevel and wider coverage of such protection.

As shown in Fig. 6, protection of the skin from the damaging effects of environmental factors (ultraviolet radiation, aerosols of industrial and chemical origin, exhaust fumes, etc.) is provided by special-purpose components that make up cosmetic kits (Cosmetics). Of particular interest is the antioxidant directed $\mathrm{La}$ Danza line, which was created both to meet cosmetic needs, and especially to protect the skin from the oxidizing effect of free radicals of the environment. 
Magnetic protection of the body consists in the use of wearing permanent magnets mounted in jewelry. In this case, a local and systemic magneto-normalizing effect is achieved, as well as «reflection» from the parasitic magnetic fields of the environment [7].

The biochemical protection of cell membranes, primarily, and nerve structures involved in regulatory processes, is achieved by the use of the latest generation of antioxidant drugs. Active neutralization of oxidizing agents, free radicals and toxic components of the external and internal environment can protect many vital systems of the body from excessive peroxidation [8].

Active biophysical protection of cell structures, energy replenishment for ATP synthesis, acceleration of regeneration processes and transport of electromagnetic waves along their conductors to stimulate nerve and metabolic processes is achieved by PILER-light (Medical). This method uses local and systemic electromagnetic waves of the biologically necessary (solar) spectrum, which determined the development and maintenance of life on Earth, and to which there are no disadaptation reactions.

It is possible to use different wavelength ranges from polychromatic to monochromatic with different types of polarization. Direct replenishment of the missing electromagnetic energy in areas experiencing its deficiency or imbalance, provides a modification of their functional state and achievement of a therapeutic effect $[4,5]$. Light therapy technology is one of the leading methods for restoring functions destroyed by the adverse effects of leading environmental factors or pathological processes.

It is important that this is a non-pharmacological approach based on the action of physical factors that can overcome natural cellular barriers that prevent drugs from entering the cell. This is especially important for contagious surfaces (mucous membranes of the nose, mouth, eyes and skin).

In this case, we focus on the advisability of prophylactic and the possibility of supportive efforts for respiratory disorders.

The effectiveness of the therapeutic effect of PILERlight can be significantly enhanced by applying the entire complex of ZEPTER technologies A sparing cooker technology (preparing of the meals in special crockery; Home Art) is used for the prevention of internal milieu of the organism from the entry of oxidizers of different genesis and of food components disrupted by high-temperature frying (roasting, grilling) or boiling. Long exposures to lower temperatures, prevention from excessive vapor formation, and vapor removal allow one to obtain meals analogous to traditional ones in their quality but with simultaneous preservation of considerable proportions of vitamins, minerals and basic food components in the state close to natural.

Preservation of ready products and semi fabricates from their further oxidation by atmospheric oxygen and from infection by microorganisms is provided by using special crockery allowing one to create and maintain vacuum (VacSy).

Using of water preliminarily purified from natural mineral admixtures and polluters, which entered from the environment (various salts, chlorine ant its compounds, heavy metals, radionuclides, pesticides, insecticides, etc.), is rather important in preparation of ecologically pure food and drinks [6]. A number of the above mentioned agents are involved in oxidation, destruction, or intoxication of the food products. This is why using of water subjected to filtration through the reverse osmosis ZEPTER systems (Home Care) provides a decrease in the level of destructions evoked by oxidizers diluted in water.

Respiration with air, cleaned from aero-ions, dust, smokes, pollen, and micro-mites, is provided by using polyfunctional vacuum cleaners and vapor sets of the CleanSy family. Their special properties are multistage hydro-cleaning, high-pressure vapor processing, and vacuum ultrafiltration. Therapy Air Ion cleaners provide a 5-step additional micro-cleaning and sterilization (microbes, viruses) of room air [2].

Thus, a health-preserving paradigm realized via the multilevel antioxidant defense against negative ecological and urbanistic influences is the main peculiarity of ZEPTER technologies in general. All this, when applied as one complex, is a necessary component of the measures used in case of acute respiratory diseases.

Methodical conclusions. In recent years, the arsenal of medical activities has expanded due to the new medical technology — light therapy with the help of BIOPTRON devices.

1. They create a unique physical factor polarized polychromatic low-intensity light with an infrared component.

2. It is possible to modify it into seven monochromatic (laser-like) ranges, a fullerene range with toroidal polarization, and into the extended range by the addition of near-UV light.

3. PILER light affects both cells and photosensitive molecules locally, normalizing their 
electromagnetic balance and systemically by affecting blood structures and acupuncture points.

4. Among the main indications are various types of the pathology of skin and mucous membranes, normalization of immunity, treatment of wounds and consequences of traumas, pain relief, optimization of the processes of postpartum development and states, subject to physiotherapy.

5. The bactericidal and antiviral efficacy of polychromatic, monochromatic and fullerene light created by Bioptron devices has been experimentally proven.

6. During the cold season, contactless noninvasive prophylaxis and treatment of colds with BIOPTRON-light therapy is essential to reduce negative effects without pharmacological load on the body.

7. There are presented tried and tested protocol schemes for prevention and treatment of acute respiratory diseases.

\section{Література.}

1. Изучение действия поляризованного света аппарата Биоптрон при летальной вирусной инфекции / Дивоча В. А., Микелашвили М. Т., Костева Т. К. // Антология светотерапии. Медицинские БИОПТРОН-технологии (теория, клиника, перспективы). - 2009. - С. 461-469.

2. Антология светотерапии. Медицинские БИОПТРОНтехнологии (теория, клиника, перспективы): Сб. научн. тр. / под ред. С. А. Гуляр. - К.: Институт физиологии им. А. А. Богомольца НАН Украины. -1024 c.

3. Gulyar S. A. From Polarization to Hyperpolarization: New Aspects of Light Therapy. Proc. of the XLIX International Scientific and Practical Conference and 22nd Gamaleya's Readings. Oct. 3-7, 2018. Hajduszoboszlo. - C. 157-162.

4. Gulyar S. A. Accents of the human body electromagnetic balance regulation system. Photobiol. and Photomed. 2018. — № 24. - С. 52-68.

5. Гуляр С. А. Медико-физиологическая стратегия компании ZEPTER и роль приборов БИОПТРОН в ее реализации / Гуляр С. А. // Антология светотерапии. Медицинские БИОПТРОН-технологии (теория, клиника, перспективы). - 2019. - С. 28-43.

6. Вода третьего тысячелетия: новые технологии очистки и анализа качества / Гуляр С. А., Кириленко Е. К. // ZEPTER Новости. — 2002. — № 16. — С. 10-12.

7. Постоянные магнитные поля и их применение в медицине / Гуляр С.А., Лиманский Ю.П. - К.: ИФБ НАНУ, 2006. - 320 c.

8. Оценка эффективности комбинированной терапии с помощью PILER-light и антиоксиданта
8. Among personal protective equipment, it is advisable to reduce the light load and create mechanical obstacles to protect the eyes by using glasses with fullerene filters.

9. The main feature of ZEPTER technologies as a whole is their health-saving essence, realized through multi-level antioxidant protection. All this is a necessary component of the measures used in case of acute respiratory diseases.

Acknowledgments. This study became possible due to support of Mr. Philip Zepter, President of the Zepter International, Ms. Diana Zepter, Chief Executive Officer of the Zepter International and Mr. Nedzad Sokoljak, Vice President of the Zepter International.

Шестой Элемент для детей, подвергшихся воздействию ионизирующего излучения после Чернобыльской аварии / Гуляр С. А., Степанова Е. И., Колпаков И. Е., Вдовенко В. Ю., Кондрашова В. Г. // Антология светотерапии. Медицинские БИОПТРОН-технологии (теория, клиника, перспективы). — 2019. C. 443-452.

9. Важность зоны применения PILER-light для эффективности светотерапии / Гуляр С. А., Колпаков И. Э. // Антология светотерапии. Медицинские БИОПТРОН-технологии (теория, клиника, перспективы). - 2019. - С. 304-311.

10. Применение БИОПТРОН-ПАЙЛЕР-света в медицине. Учебно-методическое пособие для студентов и врачей. 2-е изд., доп. / под. ред. Гуляр С. А., Косаковский А. Л. - К.: ИФБ НАН Украины, 2011. - 256 с.

11. Modification of Polychromatic Linear Polarized Light by Nanophotonic Fullerene and Graphene Filter Creates a New Therapeutic Opportunities / Gulyar S. A., Tamarova Z. A. // J. of US-China Medical Science. - 2017. — № 14 (5). — C. 173-191.

12. Фізіологічні ефекти світла з перетвореною фуллереном просторовою структурою / С. О. Гуляр, 3. А. Тамарова, Є. К. Кириленко та ін. // Медична інформатика та інженерія. — 2019. — № 1. C. 39-58.

13. Ocular Influence of Nano-Modified Fullerene Light: 1. Activity of Default Networks of the Human Brain / Gulyar S. A., Filimonova N.B., Makarchuk M. Yu., Kryvdiuk Y. N. // J of US-China Medical Science. 2019. — № 16 (2). — P. 1-15. 
14. Применение прибора БИОПТРОН в педиатрии: метод. реком. / Хан М. А., Конова О. М., Быкова М. В. - M., 2001. - 24 с.

15. Влияние БИОПТРОН-ПАЙЛЕР-света на биохимические показатели крови у детей, проживающих в регионах с радиоактивным загрязнением / Колпаков И. Е., Вдовенко В. Ю. // Антология светотерапии. Медицинские БИОПТРОН-технологии (теория, клиника, перспективы). — 2019. - C. 502-506.

16. Koruga D. Hyperpolarized Light: Fundamentals of Nano Medical Photonics / Koruga D. // Belgrade: Zepter World Book, 2017. - 306 p.

17. Опыт применения красного и синего светодиодов с инфракрасным компонентом при лечении заболеваний уха, горла и носа у детей / Косаковский А. Л., Гуляр С. А., Косаковская И. А. и др. // Современная педиатрия. — 2018. — № 89 (1). — С. 73-79.

18. Suppression of Pain by Exposure of Acupuncture Points to Polarized Light / Limansky Y. P., Tamarova Z. A., Gulyar S. A. // Pain Res. Manag. — 2006. — № 11 (1). - P. 49-57.

19. Effect of LED radiation of different wavelengths on the growth rate of Staphylococcus aureus / Pantyo V. V., Koval G. M., Pantyo V. I., Gulyar S. A. // ScienceRise: Biological Science. — 2017. — № 7 (4). — №№ 1620. - P. 43-45.

20. Influence of LED radiation on the Staphylococcus aureus sensitivity to antibiotics / Pantyo V. V., Koval G. M., Pantyo V. I., Danko E. M., Gulyar S. A. // Photobiology and Photomedicine. - 2019. № 16 (1). - P. 50-55.

21. Antinociceptive effects of color polarized light in animal with formalin test / Tamarova Z. A., Limansky Y. P., Gulyar S. А. // Фізіологічний журнал. — 2009. Т. 55, № 3. - 81-93.

22. Влияние поляризованных электромагнитных волн светового диапазона аппарата БИОПТРОН на состояние мукозального иммунитета верхних дыхательных путей у часто болеющих детей / Цодикова О. А., Бирюкова С. В., Манина 3. Н. и др. // Проблеми медичної науки та освіти. - 2004. № 2. - С. 27-30.

23. Саногенный метод коррекции неупорядоченных адаптационных реакций у детей с поляризованным светом / Цодикова О. А., Шкиряк-Нижник 3. А. // Антология светотерапии. Медицинские Биоптронные Технологии. - 2009. - С. 671-683.

\section{References.}

1. Divocha V. A., Mikelashvili M. T., Kosteva T. K. (2009). A study of the effects of polarized light generated by the Bioptron device at lethal virus infection. Anthology of Light Therapy. Medical Bioptron Technologies. Kyiv, Bogomoletz Institute of Physiology NAS of Ukraine, 461-9. [In Russian].
2. Gulyar, S. A., ed. (2009). Anthology of Light Therapy. Medical Bioptron Technologies. Kyiv, Bogomoletz Institute of Physiology NAS of Ukraine, 1-1024. [In Russian].

3. Gulyar S. A. (2018). From Polarization to Hyperpolarization: New Aspects of Light Therapy. Proc. of the XLIX International Scientific and Practical Conference and 22nd Gamaleya's Readings. Oct. 3-7, 2018. Hajduszoboszlo, 157-162.

4. Gulyar S. A. (2018). Accents of the human body electromagnetic balance regulation system. Photobiol. and Photomed. 24, 52-68.

5. Gulyar S. A. (2019). Medical-physiological strategy of the ZEPTER company and the role of BIOPTRON devices in its realization. Anthology of Light Therapy. Medical Bioptron Technologies. Kyiv, Bogomoletz Institute of Physiology NAS of Ukraine, 28-43. [In Russian].

6. Gulyar S. A., Kirilenko E. K. (2002). Water of the third millennium: novel technologies of purification and analysis of quality. ZEPTER News. 16, 10-12. [In Russian].

7. Gulyar S. A., Limansky Yu. P. (2006). Static magnetic fields and their application in medicine. Kyiv: BIPh NAS of Ukraine, 1-320. [In Russian].

8. Gulyar S. A., Stepanova E. I., Kolpakov I. E., Vdovenko V. Yu., Kondrashova V.G. (2009). Estimation of combined therapy effectiveness with PILER-light and antioxidant the Sixth Element for children exposed to ionizing radiation after Chernobyl accident. Anthology of Light Therapy. Medical Bioptron Technologies. Kyiv, Bogomoletz Institute of Physiology NAS of Ukraine, 443-52. [In Russian].

9. Gulyar S. A., Kolpakov I. E. (2009). Importance of the zone of PILER-light application for the effectiveness of light therapy. Anthology of Light Therapy. Medical BioptronTechnologies. Kyiv, Bogomoletz Institute of Physiology NAS of Ukraine, 304-311. [In Russian].

10. Gulyar S. A., Kosakovskyi A. L., eds. (2011). BioptronPILER-Light Application in Medicine (2nd ed.). Kyiv: Bogomoletz Institute of Physiology NAS of Ukraine, 1-256. [In Russian].

11. Gulyar S. A., Tamarova Z. A. (2017). Modification of Polychromatic Linear Polarized Light by Nanophotonic Fullerene and Graphene Filter Creates a New Therapeutic Opportunities. J. of US-China Medical Science,14 (5), 173-91.

12. Gulyar S. A., Tamarova Z. A., Kirilenko Ye. K., Filimonova N. B., Makarchuk N. Yu., Krivdiuk Yu. N. (2019). Physiological effects of light with spatial structure converted by fullerene. Medical Informatics and Engineering, 45 (1), 39-58. [In Russian].

13. Gulyar S. A., Filimonova N.B., Makarchuk M. Yu., Kryvdiuk Y. N. (2019). Ocular Influence of NanoModified Fullerene Light: 1. Activity of Default 
Networks of the Human Brain. J of US-China Medical Science, 16 (2), 1-15.

14. Khan M. A. (2001). Application of BIOPTRON device in pediatrics. Methodical recommendations. Moscow, 1-24. [In Russian].

15. Kolpakov I. E., Vdovenko V. Yu. (2009). Effects of BIOPTRON-PILER-light on biochemical parameters of blood in children living in regions with radioactive contamination. Anthology of Light Therapy. Medical BioptronTechnologies. Kyiv: Bogomoletz Institute of Physiology NAS of Ukraine, 502-6. [In Russian].

16. Koruga D. (2017). Hyperpolarized Light: Fundamentals of Nano Medical Photonics. Belgrade: Zepter World Book, 1-306. [In Serbian and in English].

17. Kosakovskyi A. L. Gulyar S. A., Kosakivska I. A, Grushetska N. P., Shukh L. A., Tkachenko Yu. V. (2018). Experience of using red and blue led light with infrared component in the treatment of ear, throat and nose diseases in children. Modern pediatrics, 89 (1), 73-9.

18. Limansky Y. P., Tamarova Z. A., Gulyar S. A. (2006). Suppression of Pain by Exposure of Acupuncture Points to Polarized Light. Pain Res. Manag. 11 (1), 49-57.

19. Pantyo V. V., Koval G. M., Pantyo V. I., Gulyar S. A. (2017). Effect of LED radiation of different wavelengths on the growth rate of Staphylococcus aureus. ScienceRise: Biological Science, 7 (4), 16-20; 43-45.

20. Pantyo V. V., Koval G. M., Pantyo V. I., Danko E. M., Gulyar S. A. (2019). Influence of LED radiation on the Staphylococcus aureus sensitivity to antibiotics. Photobiology and Photomedicine, 16 (1), 50-5.

21. Tamarova Z. A., Limansky Y. P., Gulyar S. A. (2009). Antinociceptive effects of color polarized light in animal with formalin test. Fiziol. J. 55 (3), 81-93. [In Ukrainian].

22. Tsodikova O. A., Biryukova S. V., Manina Z. N., Rybalka I. Y., Bobeiko A. E. (2004). Influence of polarized electromagnetic waves of the light range of the BIOPTRON device on the state of mucosal immunity of the upper respiratory tract of frequently ill children. Problems of medical science and education, 2, 27-30. [In Russian].

23. Tsodikova O. A., Shkiryak-Nizhnik Z. A. (2009). Sanogenic method for correction of disordered adaptive reactions in children with polarized light. Anthology of Light Therapy. Medical Bioptron Technologies. Kyiv, Bogomoletz Institute of Physiology NAS of Ukraine, 671-683. [In Russian]. 